\title{
Стрейн-магнитооптика - новый физический механизм модуляции ИК-излучения в ферромагнитных шпинелях
}

\author{
А.В. Телегин, Ю.П. Сухоруков, В.Д. Бессонов, А.П. Носов, С.В. Наумов \\ Институт физики металлов им. М.Н.Михеева УрО РАН, \\ Екатеринбург, 620108, С. Ковалевской, 18 \\ тел:+7 (343) 374-0230, факс:+7 (343) 374-5244, эл.nочта: telegin@imp.uran.ru
}

DOI 10.34077/RCSP2019-40

К настоящему времени в магнитных полупроводниках определены основные механизмы, формирующие спектры магнитоотражения (МО) и магнитопоглощения (МП) света в видимом и инфракрасном (ИК) диапазоне [1,2]. Важно, что магнитооптические (МО) эффекты в естественном свете в ИК-диапазоне могут быть даже больше гиротропных эффектов [2]. Известны механизмы модуляции поляризованного света в видимой области, связанные с магнитоупругими деформациями в магнетиках. В то же время, отсутствуют исследования влияния магнитоупругих деформаций на поглощение ИК-излучения в магнитострикционных материалах - объектах стрейнтроники [3].

В данной работе изучены ИК-спектры отражения и поглощения естественного света для ферримагнитной феррит-шпинели $\mathrm{CoFe}_{2} \mathrm{O}_{4}$, обладающей гигантскими значениями магнитострикции $\left(\Delta l / l=650 \cdot 10^{-6}\right)$ в магнитном поле. Монокристаллы $\mathrm{CoFe}_{2} \mathrm{O}_{4}\left(\mathrm{~T}_{\mathrm{C}}=812 \mathrm{~K}\right)$ были выращены методом бестигельной зонной плавки с радиационным нагревом. Для измерений были использованы пластины с плоскостью (001) толщиной 200-400 мкм.

$\mathrm{B}$ результате исследований монокристаллов $\mathrm{CoFe}_{2} \mathrm{O}_{4}$ было обнаружено, что внешнее магнитное поле приводит к появлению заметных эффектов МО до 4 \% и МП до $20 \%$ в широкой спектральной области от 1 мкм до 30 мкм в поле 2-3 кЭ [4]. Величина эффектов и форма спектров зависит от взаимной ориентации магнитного поля и кристаллографических осей кристалла $[5,6]$. Впервые была получена корреляция температурных и полевых зависимостей МП и МО с магнитострикцией монокристалла $\mathrm{CoFe}_{2} \mathrm{O}_{4}$. Оценка вкладов только магниторефрактивного эффекта и эффекта Фарадея не позволяет объяснить наблюдаемую величину МО эффектов. Наибольшей величины МП и МО достигают вблизи края поглощения $\left(E_{g}=1.18\right.$ эВ) и в области примесных полос поглощения. Теоретические оценки показывают, что влияние магнитного поля на оптические свойства $\mathrm{CoFe}_{2} \mathrm{O}_{4}$ является непрямым: магнитное поле вследствие магнитострикции приводит к деформации решетки, а та, в свою очередь, приводит к изменению электронной структуры феррита и, как следствие, спектров отражения и пропускания света [5].

Таким образом, в работе обнаружен новый эффективный механизм модуляции ИК-излучения в феррите, связанный с деформационно-наведенными эффектами. Большая величина МО эффектов позволяет рекомендовать феррит для использования в качестве функционального материала при создании оптоэлектронных устройств. Новая область стрейнтроники, связанная с МО эффектами в магнитострикционных материалах, названа стрейн-магнитооптикой.

Работа выполнена в рамках государственного задания ФАНО России (тема «Спин» № АAАА-А18118020290104-2), при частичной поддержке программы Уро РАН № 18-10-2-37.

\section{Лumepamypa}

[1] Ю.П. Сухоруков и др. // ЖЭТФ. 2015. Т.148, вып.3. С.503-513.

[2] A. Granovsky et al. Magnetophotonics: From Theory to Applications, Springer, 2013.

[3] А.А. Бухараев и др. // УФН. 2018. Т. 188, вып.10. С.1288-1330.

[4] Ю.П. Сухоруков и др. // Письма в ЖЭТФ. 2016. Т.104, вып.6. С.398-401.

[5] Yu. Sukhorukov et al. // Solid State Comm. 2017. V.263, p.27-33.

[6] Ю.П. Сухоруков и др. // ФММ. 2018. Т. 119, №12. С.1229-1235. 